\title{
Cukrzyca w społeczeństwie 24/7. Związek między pracą zmianową a zaburzeniami metabolicznymi
}

\author{
Diabetes in the $24 / 7$ society. The relationship between \\ shift work and metabolic disorders
}

\section{STRESZCZENIE}

We współczesnym świecie, wraz ze wzrostem tempa życia i uprzemysłowienia, zwiększa się liczba osób zatrudnionych w warunkach pracy zmianowej. Wiele wyników badań wskazuje na szkodliwość tego rodzaju zatrudnienia, traktując je jako czynnik ryzyka rozwoju wielu schorzeń, między innymi zaburzeń snu, choroby wrzodowej, nowotworów, otyłości, cukrzycy, dyslipidemii, nadciśnienia tętniczego i choroby wieńcowej. Zegar biologiczny ma kluczowy wpływ na liczne procesy fizjologiczne, począwszy od rytmu serca i ciśnienia tętniczego, a skończywszy na złożonych procesach metabolicznych. Kontrola tego mechanizmu odbywa się na poziomie neurologicznym (centralny ośrodek regulujący zegar biologiczny), hormonalnym (melatonina) i molekularnym (transkrypcja genów pre, cry, clock, bal1). Regulacja tych procesów następuje poprzez bodźce zewnętrzne (Zeitgebers), takie jak światło słoneczne, poruszanie się, jedzenie, temperatura. Praca zmianowa skutkuje zwiększonym ryzykiem występowania składowych zespołu metabolicznego, pogorszeniem funkcji poznawczych, obniżeniem od-

Adres do korespondencji:

dr n. med. Wojciech Wołyniec

Klinika Chorób Zawodowych,

Metabolicznych i Wewnętrznych

Gdańskiego Uniwersytetu Medycznego

ul. Powstania Styczniowego 9b, 81-519 Gdynia

e-mail: wolyniecwojtek@gmail.com

Diabetologia Kliniczna 2015, tom 4, 1, 22-28

DOI: $10.5603 /$ DK.2015.0004

Copyright () 2015 Via Medica

Nadesłano: 01.01.2015

Przyjęto do druku: 03.03.2015 porności, zaburzeń hormonalnych, a nawet śmierci czy samobójstwa z przepracowania. Przedstawione w niniejszej pracy zaburzenia dotyczące funkcjonowania zegarów biologicznych ukazują związek między pracą zmianową a ryzykiem otyłości, zaburzeń hormonalnych i w konsekwencji cukrzycy typu 2. (Diabet. Klin. 2015; 4, 1: 22-28)

Słowa kluczowe: cukrzyca, praca zmianowa, zespół metaboliczny, zegar biologiczny, Zeitgebers,

białko CLOCK

\section{ABSTRACT}

In the contemporary world with the high pace of life and industrialization, more and more people are getting employed on the shift work basis. So far a lot of investigations have indicated harmfulness of this kind of work, treating it as a risk factor for many diseases and medical problems i.e. sleep disorders, peptic ulcer, cancer, obesity, diabetes, dyslipidemias, high blood pressure and coronary heart disease. Biological clock plays a crucial role on physiological processes starting with heart rate and blood pressure along with complex metabolic processes. Regulation of this mechanisms takes place on few levels: neurological (central biological clock), hormonal (melatonin) and molecular (pre, cry, clock and bal1 genes transcription). External time givers (Zeitgebers) such as sunlight, moving, eating or temperature can modulate these processes. Shift work results in increase risk of metabolic syndrome, cognitive function worsening, immunodeficiency, hormones disturbances or even death or suicide from over-strain. 
This review summarizes uptodated knowledge on links between shift work and the risk of obesity, hormones disturbances and type 2 diabetes. (Diabet. Klin. 2015; 4, 1: 22-28)

Key words: diabetes mellitus, shift work, metabolic syndrome, biological clock, Zeitgebers, CLOCK protein

\section{Wstęp}

Współczesny świat, funkcjonujący 24 godziny na dobę, bywa nazywany „społeczeństwem 24/7" [1]. Od czasu wynalezienia przez Thomasa Edisona żarówki w 1879 roku systematycznie rośnie grupa osób zatrudnionych w warunkach pracy zmianowej (shift workers). Obecnie w krajach wysoce uprzemysłowionych, takich jak Polska, odsetek pracowników zmianowych wynosi ponad $20 \%[2,3]$. Wyniki wielu badań wskazują na szkodliwość pracy zmianowej (PZ). Zwiększone ryzyko wypadków w pracy, zaburzenia snu [4, 5], częste występowanie zmęczenia czy zjawisko jet lag są oczywistymi „powikłaniami ” PZ [6]. Uważa się jednak, że PZ jest także czynnikiem ryzyka rozwoju: choroby wrzodowej [6], niektórych nowotworów (raka piersi, jajnika i prostaty) $[7,8]$, a także otyłości, zespołu metabolicznego [2, 3, 9, 10], cukrzycy typu 2 (T2DM) [2, 11], dyslipidemii [10], nadciśnienia tętniczego [3,11] i choroby wieńcowej [3, 12]. Dotychczas nie udowodniono, by PZ była przyczyną zwiększonej śmiertelności [6]. Badania nad wpływem PZ wiążą się z wieloma problemami metodologicznymi. Definicja jest prosta. Pracę zmianową określa się jako pracę poza zwykłymi, dziennymi godzinami pracy [3]. Tak mało precyzyjna definicja powoduje, że grupa pracowników zmianowych jest bardzo zróżnicowana. Także „dawka” PZ jest trudna do określenia. Wydaje się, że „powikłania” PZ zależą właśnie od okresu czasu pracy w godzinach nocnych. Pracujący w systemie zmianowym poniżej 10 lat zgłaszają przede wszystkim zaburzenia snu, a u pracujących powyżej 10 lat stwierdzono zwiększone ryzyko nadciśnienia tętniczego oraz T2DM [11]. Badania epidemiologiczne obarczone są dość oczywistymi ograniczeniami, jednak są one wspierane zarówno badaniami eksperymentalnymi przeprowadzonymi na zwierzętach [13], jak i badaniami obejmującymi osoby poddawane deprywacji snu [14].

\section{Dyskusja}

Zegar biologiczny

Nie sposób zaprzeczyć istnieniu zegara biologicznego. Każdy człowiek doświadcza skutków cykliczności procesów życiowych. Stosunkowo rzadko jednak wykorzystuje się tę wiedzę we współczesnej medycynie. Dodat- kowo powiązanie tego tematu z paramedycyną (rozmaite rytmy biologiczne, horoskopy itp.) zniechęca naukowców do poważnego traktowania tematu zegara biologicznego.

Jako pierwszy istnienie zegara biologicznego wykazał francuski astronom Jean Jacques d'Ortous de Marian w 1729 roku, wykonując słynne doświadczenie z mimozą (Mimosa pudica), która otwierała i zamykała swoje liście zależnie od pory dnia, mimo zamknięcia w ciemności, bez wpływu światła [15]. W 1823 roku szwajcarski botanik Augustin Pyramus de Candolle powtórzył doświadczenie de Mairana, tworząc podstawy chronobiologii [16]. De Marian i jego następca wykazali 24-godzinną cykliczność życia (circadian rhythm, od łac. circa diem) [3]. Pod kontrolą rytmu dobowego znajdują się rytm snu i czuwania, spożywanie pokarmów, termoregulacja i wiele innych procesów [3]. Życiem rządzą też cykle krótsze (ultradian rhythms) dla procesów zmieniających się wielokrotnie w ciągu 24 godzin oraz cykle dłuższe - jak miesięczny (np. cykl menstruacyjny) czy roczne (circannual rhythms) [3].

Codzienna aktywność wszystkich organizmów na Ziemi zależy od jej ruchów wokół Słońca. Dlatego to światło słoneczne jest najsilniejszym czynnikiem regulującym zmienność cyklów życia, ale nie jest jedynym. Wewnątrzkomórkowe zegary biologiczne powstały po to, by wyprzedzać (antycypować) pory dnia, tak aby żywy organizm mógł funkcjonować efektywniej w stale zmieniającym się świecie. Te wewnętrzne rytmy, dotyczące wszystkich komórek organizmu, mają cykl nieznacznie dłuższy niż 24 godziny [17]. Musi on być zatem codziennie „dostrajany” przez ośrodek centralny, który z kolei podlega światu zewnętrznemu. Zmienność dobową wykazują: rytm serca, ciśnienie tętnicze, przepływ krwi, funkcje śródbłonka, napięcie naczyń czy aktywność fibrynolityczna [18]. Te zmienności dobowe funkcjonowania układu sercowo-naczyniowego tłumaczą miedzy innymi występowanie większej częstości zawałów serca wcześnie rano [18-20].

Wykazano także dobową cykliczność procesów metabolicznych, dotyczącą głównie metabolizmu glukozy i tłuszczów [3] oraz układu wydzielania auto-, parai endokrynnego [10]. Zmienność dobową wykazują między innymi stężenia insuliny, greliny, leptyny [18], melatoniny i glikokortykosteroidów [3]. Kluczowe enzymy w wątrobie, tkance tłuszczowej i trzustce również są zależne od rytmów biologicznych, a w niektórych tkankach (np. wątrobie, sercu) ekspresja aż 20\% genów wykazuje zmienność dobową [13, 18, 19].

Glukoza jest jedną z wielu substancji charakteryzująca się dobową zmiennością stężenia we krwi. Poranny wzrost stężenia glukozy następuje przed przebudzeniem się [21]. Jest to jeden z przykładów „przewidywania” przez zegary biologiczne zwiększonej aktywności organizmu. 


\section{Ośrodek centralny}

Ośrodek centralny regulujący zegar biologiczny znajduje się $w$ jądrach nadskrzyżowaniowych (SCN, suprachiasmatic nucleus, łac. suprachiasmatic nucleus) w podwzgórzu. SCN, znajdujące się ponad skrzyżowaniem nerwów wzrokowych, mają za zadanie koordynowanie innych zegarów biologicznych, na przykład znajdujących się w tkankach metabolicznie czynnych, takich jak tkanka tłuszczowa $[18,22,23]$. Aktywność tego centralnego zegara biologicznego regulowana jest przede wszystkim światłem. SCN poprzez wpływ na czynniki humoralne, autonomiczny układ nerwowy i termoregulację narzucają organizmowi „wystandaryzowany" czas lub, inaczej mówiąc, synchronizują molekularne zegary biologiczne w tkankach i komórkach obwodowych $[23,24]$ w celu optymalizacji funkcji życiowych i dopasowania metabolizmu do zachowania organizmu: spożywania pokarmu, zwiększonej aktywności fizycznej, czuwania i snu [14]. Wpływają na produkcję melatoniny, ale także podlegają jej wpływowi, co stanowi jedno $z$ wielu istotnych dla utrzymania cykliczności życia sprzężeń zwrotnych [17].

\section{Melatonina}

Melatonina jest hormonem syntetyzowanym w szyszynce, odgrywającym ważną rolę w humoralnej kontroli rytmów biologicznych. Sekrecja zależy od pory dnia i jest największa w nocy. U ludzi wydzielanie szyszynki jest kontrolowane przez impulsy wysyłane przez siatkówkę oka. Wydzielanie melatoniny podlega kontroli zwoju szyjnego górnego, do którego są przekazywane impulsy z siatkówki oka. Melatonina odgrywa rolę w rytmach dobowych, procesach neuroendokrynnych, wpływa na wychwyt glukozy przez adipocyty i mięśnie [2], stymuluje ekspresję leptyny, wpływa na wydzielanie hormonów płciowych, $w$ tym estrogenów $[2,7]$. Wyniki badań doświadczalnych przeprowadzonych na szczurach wykazały, że usunięcie szyszynki powoduje nietolerancję glukozy wynikającą z braku melatoniny. Do zaburzeń gospodarki węglowodanowej nie dochodziło bowiem u szczurów po pinealektomii, którym podawano melatoninę. Wykazano także, że u potomstwa szczurów, którym usunięto szyszynkę, także rozwija się nietolerancja glukozy. Dochodziło u nich do rozwoju insulinooporności komórek wątrobowych i zwiększonej glukoneogenezy [2].

\section{Zegary molekularne}

Zegary molekularne znajdują się we wszystkich komórkach organizmu, zarówno w SCN, jak i w tkankach obwodowych. Rytm dobowy jest wynikiem wzajemnych sprzężeń między odpowiednimi genami i ich produktami. Zegary biologiczne w tkankach obwodowych nie są bezpośrednio zależne od wpływu światła słonecznego. Dwa białka są kluczowe dla kontroli zegara biologicznego - białko CLOCK (circadian locomotor output cycles kaput) i BMAL1 (brain and muscle ARNT like protein 1), kodowane przez geny clock i bmal1. Białka CLOCK i BMAL1 tworzą kompleks CLOCK/BMAL1, który poprzez ujemne sprzężenie zwrotne hamuje ich własną transkrypcję [23]. Wykazano także zależność między genami per (Period) i cry (Crptochrome), kodującymi białka PER i CRY, a kompleksem białek CLOCK/BMAL1. Kompleks CLOCK/BMAL1 aktywuje z kolei transkrypcje genów per i cry, a kodowane przez nie białka PER i CRY hamują CLOCK/BMAl1 [18]. Poza genami clock, bmal1, per i cry za rytmy dobowe odpowiadają także między innymi geny: dec1/2, rev-erba(alfa), dbp/hlf/tef, e4bp4 [19, 20]. Ekspresja matrycowego kwasu rybonukleinowego (mRNA) dla tych genów wykazuje znaczną oscylację w ciągu doby $w$ wielu komórkach ciała $[19,20]$. W badaniach eksperymentalnych wykazano, że mutacje genu clock powodują rozwój zespołu metabolicznego [3], polimorfizmy tego genu korelują z otyłością [25], a mutacje genu bmal1 wiązano z rozwojem T2DM i nadciśnienia tętniczego [26].

\section{Zeitgebers}

Wewnątrzkomórkowy zegar biologiczny może zostać "zresetowany" przez silne bodźce, tak zwane Zeitgebers. Jest to pojęcie używane także w piśmiennictwie anglojęzycznym, rzadziej używana nazwa to time-giver. Są to między innymi: światło słoneczne, aktywność fizyczna, temperatura otoczenia, jedzenie, które silnie wpływają na zegar biologiczny. Dzieje się tak poprzez zmiany temperatury ciała, działanie neurotransmiterów (np. glutaminian, adrenalina), wpływ pokarmu i metabolitów (glukoza), wpływ hormonów auto-, para- i endokrynnych (glikokortykoidy, adrenalina, angiotensyna) $[19,20]$. Zeitgebers pozwalają wyregulować, "dostroić" zegar biologiczny, co jest konieczne, ponieważ naturalny cykl wewnątrzkomórkowego zegara jest nieco dłuższy niż 24 godziny.

\section{Zaburzenia stwierdzane w pracy zmianowej}

Praca zmianowa wiąże się ze zmienioną ekspozycją na światło, zwiększoną aktywnością fizyczną w godzinach nocnych, zmianą pory spożywania pokarmu i jego składem. Wszystkie te czynniki to Zeitgebers, mogące wpływać na funkcjonowanie zegarów biologicznych i - jak się wydaje - powodować choroby metaboliczne. Nie jest jasne, na które z zaburzeń PZ wpływa bezpośrednio poprzez zaburzenie rytmów biologicznych, a które wynikają z trybu życia, na przykład sposobu spędzania wolnego czasu, zwykle mało aktywnego u osób pracujących w systemie PZ [6]. 


\section{Czas pracy}

Pracownicy zmianowi stanowią grupę osób o niższym, w porównaniu z pracującymi tylko w dzień, statusie ekonomicznym [27], a podjęcie PZ często wiąże się z wydłużeniem czasu pracy [27]. Wydłużenie godzin pracy w „normalnych", niezmianowych godzinach [28] także powoduje zaburzenia snu i częstsze występowanie choroby wieńcowej [28], T2DM [29] oraz odpowiada za przypadki koroshi (śmierć z przepracowania) i karojisatsu (samobójstwo z przepracowania) [28]. We współczesnym świecie długo (tzn. ponad 50 godzin tygodniowo) pracuje $22 \%$ pracowników na świecie (np. w Korei 50\%, a we Francji 14,7\%) [28].

\section{Sen}

Wiadomo, że zaburzenia snu, także te niewynikające z pracy (jak bezsenność, nocny tryb życia) niekorzystnie wpływają na zdrowie [13]. Krótki sen wiąże się z ryzykiem otyłości, wyższego wskaźnika masy ciała, T2DM, zwiększonej porannej śmiertelności $[5,14]$. We współczesnym świecie skraca się czas snu, w 1960 roku respondenci deklarowali przesypianie średnio 8 godzin, a w 1995 roku już tylko średnio około 7 godzin [5]. Długi, dobry sen potrzebny jest dla prawidłowego funkcjonowania czynności intelektualnych, pamięci, ale także dla prawidłowego metabolizmu i czynności układu immunologicznego [17]. W przypadku zaburzeń snu dochodzi do zaburzeń kontroli centralnego ośrodka nad tkankami obwodowymi [14]. Wykazano, że na zaburzenia snu bardziej wrażliwe są kobiety [17].

\section{Brak światła}

Brak światła (PZ, nocny tryb życia, jet lag, osoby niewidome, długie zimowe noce) powoduje zaburzenia pracy SCN i zaburzenia snu [17]. Zaburzenia wydzielania melatoniny związane z brakiem światła są jedną z przyczyn nietolerancji glukozy [13].

\section{Styl życia i zwyczaje żywieniowe}

Otyłość występującą wśród pracowników zmianowych tłumaczy się nie tylko zaburzeniem funkcjonowania zegarów biologicznych, ale także zmianą zwyczajów żywieniowych i stylu życia [3]. Najczęściej PZ jest statyczna, podczas gdy wysiłek fizyczny w pracy ma według wielu autorów ochrony wpływ na układ sercowo-naczyniowy [30, 31]. Pracownicy zmianowi częściej spożywają posiłki bogate w tłuszcze. Według niektórych autorów liczba spożywanych kcal jest taka jak przy pracy dziennej [3], według innych pracownicy zmianowi spożywają $200 \mathrm{kcal} /$ dobę więcej [14]. W badaniach doświadczalnych przeprowadzonych na modelu zwierzęcym wykazano, że zmienione pory spożywania posiłków odpowiadają za nietolerancję glukozy, nawet jeśli skład posiłków nie ulegał zmianie [3, 32]. W zależności od pory dnia spożywania pokarmu zmienia się też wpływ pokarmu na termogenezę, co może tłumaczyć, dlaczego jedząc tyle samo, pracownicy zmianowi szybciej tyją [33].

\section{Zaburzenia hormonalne}

Praca zmianowa i ograniczenie snu $[14,24]$ prowadzą do spadku stężenia leptyny i zwiększonego apetytu [14, 24]. Wśród osób wykonujących PZ po posiłku stężenie greliny (hormon łaknienia) obniża się mniej, a stężenie kseniny (hormonu sytości) mniej wzrasta w porównaniu z grupą kontrolną [14, 34]. Wykazano, że w przypadku przewlekłej restrykcji snu dochodzi do 32-procentowej redukcji wydzielania insuliny po przyjęciu standardowego pokarmu [14].

\section{Praca zmianowa jako czynnik}

\section{ryzyka zachorowania na cukrzycę typu 2}

Przedstawione powyżej zaburzenia funkcjonowania zegarów biologicznych powodują zmiany w homeostazie glukozy i lipogenezie. Uważa się, że prowadzi to do rozwoju T2DM [3], otyłości i zespołu metabolicznego [9]. W modelu zwierzęcym T2DM (szczury HIP) stwierdzono szybszy rozwój cukrzycy po 10 tygodniach zaburzonego rytmu dobowego. W porównaniu z grupą kontrolną wykazano bardziej nasilone zaburzenia dotyczące wydzielania insuliny w odpowiedzi na stężenie glukozy i szybszą utratę komórek beta trzustki. Badanie to sugeruje, że w przypadku osób zagrożonych rozwojem T2DM praca zmianowa może się stać istotnym czynnikiem ryzyka [13]. Wśród badań analizujących wpływ PZ na T2DM u ludzi należy zwrócić uwagę na heterogeniczność ocenianych grup, częsty brak analizy na podstawie współwystępowania innych czynników ryzyka, brak informacji o jakości wykonywanej pracy, czas rozpoczęcia i zakończenia PZ. Trzeba pamiętać też, że praca nadliczbowa również zwiększa 3,7-krotnie ryzyko wystąpienia cukrzycy [8]. Jednak wyniki wielu badań jednoznacznie wskazują na wpływ PZ na rozwój cukrzycy.

W historycznej pracy z 1983 roku, w której badano 9 tysięcy pracowników japońskiej fabryki, stwierdzono wyższą częstość T2DM wśród pracowników zmianowych w porównaniu z grupą kontrolną ( $2,1 \%$ vs. 0,9\%) [35]. Podobnie w obszernej analizie grupy niemieckiej, w której oceniono 14 tysięcy mężczyzn pracujących w trybie zmianowym oraz 17 tysięcy w trybie dziennym w latach 1996-2006, wykazano częstsze występowanie T2DM wśród pracowników zmianowych, nawet po uwzględnieniu innego, kluczowego czynnika ryzyka T2DM, jakim jest otyłość (ryzyko względne RR = 1,39). Jednocześnie autorzy podkreślali podobną częstość 
zgonów w obu grupach. Oceniali także, że system zmianowy 12-godzinny (zmiany o godzinie 6.00 i 18.00) ma najmniejszy niekorzystny wpływ na dysregulacje rytmów okołodobowych [36]. Z kolei Morikawa i wsp. [37] stwierdzili, że największe ryzyko wystąpienia T2DM istnieje wśród osób pracujących w systemie 2-zmianowym - RR 6,84, przy RR 5,3 wśród pracowników w systemie 3-zmianowym oraz RR 3,34 wśród osób pracujących w systemie dziennym [37]. W badaniu Tongji-Dongfeng Cohort Study obejmującym 26462 emerytów zanotowano wyższe stężenia glukozy na czczo u osób pracujących co najmniej 1 rok w trybie zmianowym (6,10 vs. 6,02 mmol/l; $p<0,01)$. W badaniu tym oceniono, że PZ trwająca ponad 10 lat wiązała się z częstszym występowaniem nadciśnienia tętniczego i T2DM, choć autorzy podkreślają jej znamiennie istotny wpływ dopiero po 20 latach PZ. W analizie zabrakło oceny nawyków żywieniowych badanych, co mogło wpływać na ostateczne rezultaty [11]. W badaniach Nurses' Heath Study I (NHS I) i Nurses' Heath Study II (NHS II), w których wzięło udział ponad 170 tysięcy pielęgniarek w wieku 25-67 lat, wykazano większą częstość T2DM wśród pracowników zmianowych. Znaczenie miała liczba przepracowanych lat. Dla PZ dłuższej niż 20 lat ryzyko względne wynosiło 1,58 [38, 39]. Co ważne, w tym badaniu wykazano zwiększone ryzyko T2DM po uwzględnieniu wartości wskaźnika masy ciała. W analizie ponad 62 tysięcy uczestniczek badania NHS II wykazano, że T2DM częściej występuje nie tylko wśród osób pracujących w trybie zmianowym, ale także w grupie pracującej powyżej 41 godzin tygodniowo [29].

Praca zmianowa jest szczególnie niebezpieczna dla osób z nieprawidłową glikemią na czczo lub nieprawidłową tolerancją glukozy. Podczas 3-letniej obserwacji w tej grupie pracowników ryzyko rozwoju cukrzycy było 5-krotnie wyższe niż w grupie kontrolnej [14]. Poza wpływem na rozwój otyłości i nieprawidłowymi nawykami żywieniowymi na rozwój zaburzeń gospodarki węglowodanowej wpływa także sama deprywacja snu. W badaniu The Dunedin Multidisciplinary Heath and Development Study obejmującym 1037 osób bez cukrzycy w wieku 32 lat deklarowana długość snu korelowała negatywnie $z$ wartością hemoglobiny glikowanej $\left(\mathrm{HbA}_{1 c^{\prime}} ; \mathrm{p}=0,002\right)$ i zwiększonym ryzykiem prediabetes $(p=0,015)[40]$.

W najnowszej metaanalizie, opublikowanej w 2015 roku, a obejmującej łącznie 226652 badanych wykazano zwiększone o 9\% ryzyko wystąpienia T2DM u pracowników zmianowych. Dotyczyło to zwłaszcza mężczyzn. Może być to wynikiem hipoandrogenizmu, który wiąże się z insulinoopornością i T2DM u mężczyzn. Stężenie testosteronu oraz wielu innych hormonów jest regulowane poprzez rytmy okołodobowe [41]. W innym niedawno przeprowadzonym przeglądzie systematycznym dotyczącym zależności PZ i T2DM [42] analizowano wyniki badań Karlssona i wsp. z 2005 roku, które wskazują na zwiększoną śmiertelność związaną z cukrzycą wraz z wydłużaniem się stażu pracy w trybie PZ [43].

\section{Praca zmianowa jako czynnik}

złej kontroli cukrzycy

Ze względu na niekorzystny wpływ PZ na regularność spożywania pokarmów, a także poprzez wspomniane wyżej zjawisko zmniejszonego wyrzutu insuliny w odpowiedzi na pokarm PZ wydaje się w istotny sposób oddziaływać na kontrolę przebiegu cukrzycy. Stosunkowo niewiele badań podejmuje jednak ten temat, dotyczą one głównie cukrzycy typu 1 (T1DM). W badaniu z 1992 roku nie stwierdzono wpływu PZ na pogorszenie kontroli cukrzycy, analizowano jednak małą grupę 32 osób, a stężenia $\mathrm{HbA}_{1 c}$ były bardzo wysokie - w grupie pracowników zmianowych 10,1\%, a w grupie kontrolnej 10,5\% [44]. W nowszym badaniu wśród 295 chorych na T1DM zanotowano statystycznie wyższe stężenia $\mathrm{HbA}_{1 \mathrm{c}}$ u osób pracujących w trybie zmianowym w porównaniu z grupą kontrolą (9,0\% vs. 8,35\%) [45]. Badacze z Tajlandii oceniali wpływ PZ na średnie wartości glikemii na czczo w ciągu 6 miesięcy, przyjmując stężenie $<7,22 \mathrm{mmol} / \mathrm{l}$ za dobrze kontrolowaną cukrzycę. Wykazano, że 28\% pracowników dziennych i tylko 15,8\% pracowników zmianowych spełniało kryteria dobrze wyrównanej DM $(p=0,02)$. Obserwowano istotnie więcej incydentów hipoglikemii u pracowników zmianowych (43\%) w porównaniu z pracownikami dziennymi (27\%; p $=0,01$ ) [46]. Badania wpływu PZ na T2DM sugerują, że jednym z celów terapii u tych pacjentów, poza modyfikacją stylu życia w postaci zwiększenia wysiłku fizycznego i wprowadzenia diety ubogotłuszczowej, powinno być zastosowanie leku korygującego zaburzenia związane z rytmem okołodobowym. Takim preparatem, który mógłby być stosowany łącznie z odpowiednim dawkowaniem jasnego światła, jest melatonina. Jest ona lekiem bezpiecznym, korzystnie wpływającym na niektóre czynniki ryzyka sercowo-naczyniowego i zaburzenia metaboliczne współwystępujące w T2DM [47].

\section{Wnioski}

Celem diabetologów jest edukacja, leczenie i rehabilitacja chorych na cukrzycę, aby mogli oni stanowić integralną cześć społeczeństwa. Praca w systemie zmianowym we współczesnym społeczeństwie dotyczy coraz większej liczby osób. W sposób naturalny znajdują się wśród nich osoby zagrożone rozwojem cukrzycy 
i już na nią chorujące. Celem niniejszego opracowania było zwrócenie uwagi na wpływ pracy zmianowej na występowanie cukrzycy i jej przebieg.

\section{Oświadczenie o konflikcie interesów} Autorzy nie zgłaszają konfliktu interesów.

\section{PIŚMIENNICTWO}

1. Williams S.J., Coveney C.M., Gabe J. Medicalisation or customisation? Sleep, enterprise and enhancement in the $24 / 7$ society. Soc. Sci. Med. 2013; 79: 40-47.

2. Ferreira D.S., Amaral F.G., Mesquita C.C. i wsp. Maternal melatonin programs the daily pattern of energy metabolism in adult offspring. PLoS One 2012; 7: e38795.

3. Antunes L.C., Levandovski R., Dantas G., Caumo W., Hidalgo M.P. Obesity and shift work: chronobiological aspects. Nutr. Res. Rev. 2010; 23: 155-168.

4. Flo E., Pallesen S., Åkerstedt T. i wsp. Shift-related sleep problems vary according to work schedule. Occup. Environ. Med. 2013; 70: 238-245.

5. Husse J., Hintze S.C., Eichele G., Lehnert H., Oster H. Circadian clock genes Per1 and Per2 regulate the response of metabolism-associated transcripts to sleep disruption. PLoS One 2012; 7: e52983.

6. Knutsson A. Health disorders of shift workers. Occup. Med. (Lond.) 2003; 53: 103-108.

7. Bhatti P., Cushing-Haugen K.L., Wicklund K.G., Doherty J.A., Rossing M.A. Nightshift work and risk of ovarian cancer. Occup. Environ. Med. 2013; 70: 231-237.

8. Ika K., Suzuki E., Mitsuhashi T., Takao S., Doi H. Shift work and diabetes mellitus among male workers in Japan: does the intensity of shift work matter? Acta Med. Okayama 2013; 67: 25-33.

9. Pietroiusti A., Neri A., Somma G., Coppeta L., lavicoli I., Bergamaschi A., Magrini A. Incidence of metabolic syndrome among night-shift healthcare workers. Occup. Environ. Med. 2010; 67: 54-57.

10. Karlsson B.H., Knutsson A.K., Lindahl B.O., Alfredsson L.S. Metabolic disturbances in male workers with rotating three-shift work. Results of the WOLF study. Int. Arch. Occup. Environ. Health. 2003; 76: 424-430.

11. Guo Y., Liu Y., Huang X. i wsp. The effects of shift work on sleeping quality, hypertension and diabetes in retired workers. PLoS One 2013; 8: e71107.

12. Yadegarfar G., McNamee R. Shift work, confounding and death from ischaemic heart disease. Occup. Environ. Med. 2008; 65:158-163.

13. Gale J.E., Cox H.I., Qian J., Block G.D., Colwell C.S., Matveyenko A.V. Disruption of circadian rhythms accelerates development of diabetes through pancreatic beta-cell loss and dysfunction. J. Biol. Rhythms 2011; 26: 423-433.

14. Buxton O.M., Cain S.W., O'Connor S.P. i wsp. Adverse metabolic consequences in humans of prolonged sleep restriction combined with circadian disruption. Sci. Transl. Med. 2012; 4: 129 ra43.

15. Zordan M., Costa R., Macino G., Fukuhara C., Tosini G. Circadian clocks: what makes them tick? Chronobiol. Int. 2000; 17: 433-451.

16. McClung Robertson C. Plant circadian rhythms. The Plant Cell. 2006; 18: 792-794.

17. Porkka-Heiskanen T., Zitting K.M., Wigren H.K. Sleep, its regulation and possible mechanisms of sleep disturbances. Acta Physiol. (Oxf.) 2013; 208: 311-328.

18. Duez H., Staels B. Nuclear receptors linking circadian rhythms and cardiometabolic control. Arterioscler. Thromb. Vasc. Biol. 2010; 30:1529-1534.
19. Young M.E. Anticipating anticipation: pursuing identification of cardiomyocyte circadian clock function. J. Appl. Physiol. (1985) 2009; 107: 1339-1347.

20. Young M.E. The circadian clock within the heart: potential influence on myocardial gene expression, metabolism, and function. Am. J. Physiol. Heart Circ Physiol. 2006; 290: H1-H16.

21. Bailey S.M., Udoh U.S., Young M.E. Circadian regulation of metabolism. J. Endocrinology 2014; 222: R75-R96.

22. Allebrandt K.V., Roenneberg T. The search for circadian clock components in humans: new perspectives for association studies. Braz. J. Med. Biol. Res. 2008; 41: 716-721.

23. Bass J., Takahashi J.S. Circadian integration of metabolism and energetics. Science 2010; 330: 1349-1354.

24. Mathew D., Zhou P., Pywell C.M. i wsp. Ablation of the ID2 gene results in altered circadian feeding behavior, and sex-specific enhancement of insulin sensitivity and elevated glucose uptake in skeletal muscle and brown adipose tissue. PLoS One 2013; 8: e73064.

25. Scott E.M., Carter A.M., Grant P.J. Association between polymorphisms in the Clock gene, obesity and the metabolic syndrome in man. Int. J. Obes. (Lond.) 2008; 32: 658-662.

26. Woon P.Y., Kaisaki P.J., Bragança J. i wsp. Aryl hydrocarbon receptor nuclear translocator-like (BMAL1) is associated with susceptibility to hypertension and type 2 diabetes. Proc. Natl. Acad. Sci. USA 2007; 104: 14412-14417.

27. Kivimäki M., Batty G.D., Hublin C. Shift work as a risk factor for future type 2 diabetes: evidence, mechanisms, implications, and future research directions. PLoS Med. 2011; 8: e1001138.

28. Bannai A., Tamakoshi A. The association between long working hours and health: a systematic review of epidemiological evidence. Scand J. Work Environ Health 2014; 40: 5-18.

29. Kroenke C.H., Spiegelman D., Manson J., Schernhammer E.S., Colditz G.A., Kawachi I. Work characteristics and incidence of type 2 diabetes in women. Am. J. Epidemiol. 2007; 165: 175-183.

30. Morris C.J., Yang J.N., Scheer F.A. The impact of the circadian timing system on cardiovascular and metabolic function. Prog. Brain Res. 2012; 199: 337-358.

31. Makowiec-Dabrowska T., Bortkiewicz A., Gadzicka E. Physical effort at workplace: a risk factor for or a protection against the development of cardiovascular diseases. Med. Pr. 2007; 58: 423-432.

32. Bhutta H.Y., Deelman T.E., Ashley S.W., Rhoads D.B., Tavakkoli A. Disrupted circadian rhythmicity of the intestinal glucose transporter SGLT1 in Zucker diabetic fatty rats. Dig. Dis. Sci. 2013; 58: 1537-1545.

33. Crispim C.A., Zalcman I., Dáttilo M. i wsp. The influence of sleep and sleep loss upon food intake and metabolism. Nutr. Res. Rev. 2007; 20: 195-212.

34. Schiavo-Cardozo D., Lima M.M., Pareja J.C., Geloneze B. Appetite-regulating hormones from the upper gut: disrupted control of xenin and ghrelin in night workers. Clin. Endocrinol. (Oxf.) 2013; 79: 807-811.

35. Mikuni E., Ohoshi T., Hayashi K., Miyamura K. Glucose intolerance in an employed population. Tohoku J. Exp. Med. 1983; 141: 251-256.

36. Oberlinner C., Ott M.G., Nasterlack M. i wsp. Medical program for shift workers - impacts on chronic disease and mortality outcomes. Scand. J. Work Environ. Health 2009; 35: 309-318.

37. Morikawa Y., Nakagawa H., Miura K i wsp. Shift work and the risk of diabetes mellitus among Japanese male factory workers. Scand. J. Work Environ. Health 2005; 31: 179-183.

38. Pan A., Schernhammer E.S., Sun Q., Hu F.B. Rotating night shift work and risk of type 2 diabetes: two prospective cohort studies in women. PLoS Med 2011; 8: e1001141.

39. Axelsson J., Puttonen S. Night shift work increases the risk for type 2 diabetes. Evid. Based Med. 2012; 17: 193-194.

40. Hancox R.J., Landhuis C.E. Association between sleep duration and haemoglobin A1c in young adults. J. Epidemiol. Community Health 2012; 66: 957-961. 
41. Gan Y., Yang C., Tong X. i wsp. Shift work and diabetes mellitus: a meta-analysis of observational studies. Occup. Environ. Med. 2015; 72: 72-78.

42. Knutsson A., Kempe A. Shift work and diabetes: a systematic review. Chronobiol. Int. 2014; 31: 1146-1151.

43. Karlsson B., Alfredsson L., Knutsson A., Andersson E., Torén K. Total mortality and cause-specific mortality of Swedish shift- and dayworkers in the pulp and paper industry in 1952-2001. Scand. J. Work Environ. Health. 2005; 31: 30-35.
44. Poole $C$ J Wright A D Nattrass $M$ Control of diabetes mellitus in shift workers. Br. J. Ind. Med. 1992; 49: 513-515.

45. Young J., Waclawski E., Young J.A., Spencer J. Control of type 1 diabetes mellitus and shift work. Occup. Med. (Lond.) 2013; 63: 70-72.

46. Chalernvanichakorn T., Sithisarankul P., Hiransuthikul N. Shift work and type 2 diabetic patients' health. J. Med. Assoc. Thai. 2008; 91: 1093-1096.

47. Karthikeyan R., Marimuthu G., Spence D.W. i wsp. Should we listen to our clock to prevent type 2 diabetes mellitus? Diabetes Res. Clin. Pract. 2014; 106: 182-190. 